\title{
CASE COMMENT: LIES MY POLITICIAN TOLD ME: FRIESEN v. HAMMEL AND THE NATURE OF ELECTION FRAUD
}

\section{ANDREW HEARD ${ }^{\bullet}$}

What many viewed simply as an amusing news story in British Columbia has turned into a serious case against the Premier, all other government MLAs, and the B.C. New Democratic Party. Shortly after the 1996 provincial election, three British Columbian voters filed a motion in the provincial Supreme Court alleging that they had been fraudulently induced into voting for the NDP by lies about the state of the province's finances. This case raises interesting issues about the standard of honesty that candidates must observe while campaigning. As the case proceeds, the court will also face some knotty problems over cabinet confidentiality in the search to find out just what the premier and his colleagues knew when about the government's finances. The larger issue, however, is what constitutes "fraudulent means" that a candidate or party cannot use to induce a person to vote for them. Should the fraud be restricted to a loss relating to some economic interest, or can it be given a broader context that encompasses even the value of a voter's freedom to choose among candidates?

Lawyers for the three aggrieved voters allege that the NDP, party and candidates, campaigned on the statement that the province's budget was balanced and promised a significant program of capital spending because of the surplus, all at a time when members of the government knew that the province was facing a serious shortfall. Indeed, within weeks of being re-elected, the Clark government announced a moratorium on government construction projects and eventually revealed that the province was heading for a significant deficit, even with corrective action. The petitioners started a suit, both in their own right and as a class action, seeking an injunction under the Election Act to order that the elections of the sitting NDP members be declared invalid. In late February 1997, Esson C.J. rejected motions by the respondents to have the case dismissed, setting the stage for one of the most interesting cases to probe into how politicians behave during elections.' This case goes well beyond the usual election skulduggery of free liquor, cash-filled handshakes, fresh gravel for rural driveways, and inducing unqualified persons to vote.

Several issues with far-reaching consequences are raised. At stake is the nature of campaign promises and the limits to the gloss that incumbents put on their record in office. The very essence of an election campaign is the stuff of exaggeration - "We've been a marvellous government and we promise to provide you with even more wonders if you vote for us!" At what point does this approach to campaigning reach such levels of dishonesty that a candidate becomes liable to a charge of using fraudulent means to garner support? In the course of dealing with the Friesen case, the court will have to examine what constitutes "fraudulent means" in the context of election campaigns. And, if it is to get to the bottom of the allegations, it will have to try to ascertain what the premier and his colleagues knew when. While some documents have been made public 
by journalists, much more remains to be learned from cabinet documents that will not be released to the court without considerable argument.

Ironically, the disgruntled voters were able to launch this case only because of amendments to the Election Act that the NDP government had brought in less than two years earlier. While Mike Harcourt was still leader of the NDP and Premier in 1995, a range of changes were made to the Act, including a re-working of Part XII dealing with offences. Section 256 embodies language not found in any other election law in Canada:

256(2) An individual or organization must not, by abduction, duress or fraudulent means, do any of the following:

(a) impede, prevent or otherwise interfere with an individual's right to vote;

(b) compel, persuade or otherwise cause an individual to vote or refrain from voting;

(c) compel, persuade or otherwise cause an individual to vote or refrain from voting for a particular candidate or for a candidate of a particular political party.

(3) An individual or organization prohibited from doing something by this section must not do the prohibited act directly, indirectly or by another individual or organization on behalf of the individual or organization who is subject to the prohibition. ${ }^{2}$

At the heart of the allegations in Friesen is the prohibition against using "fraudulent means" to "persuade or otherwise cause an individual to vote ... for a candidate of a particular party." The petitioners state that they voted for the NDP candidates because of NDP claims that the provincial budget would have a surplus and that the government would be able to undertake a $\$ 250$ million capital development program on a variety of construction projects. Had the petitioners known that there would be no budget surplus and no capital spending, they claim that they would not have voted for the NDP candidates. They allege that the Premier and his colleagues knew the truth during the campaign about the impending deficit and deliberately hid the facts. While it is clear that not all the NDP candidates or the party itself would have been privy to the budget details, it is alleged that the Premier and some of his cabinet colleagues knew the truth but continued to allow the party and its candidates to disseminate falsehoods in order to get elected. The issues boil down to what did the Premier and his colleagues know when, did they not tell the truth during the campaign, and did any of this constitute "fraudulent means"?

It will take the process in the Supreme Court to ascertain the facts of the case and it would be foolish to speculate here about whether lies were told. However, the public

R.S.B.C. 1996, c. 106. Alberta has a provision which prohibits fraudulent practise that results in someone voting or not voting at all. See Election Act, R.S.A. 1980, c. E-2, s. 171(1)(b). B.C. differs by tying the fraudulent behaviour to a person's decision to vote for a particular candidate or party. 
record indicates at least some prima facie evidence that may be used to consider the nature of campaign fraud in s. 256. Journalists uncovered memos from bureaucrats that indicated their alarm that the government was projecting a budget surplus. Much of the problem stemmed from greatly reduced royalties from the forestry industry that were evident from early 1996. The government argued that its projected surplus was based on economic forecasts made by private industry. They had chosen one of the most optimistic forecasts available, but it was still a projection based on independent economic analysis. However, there is some speculation that the government receipts had shown such deterioration by the May provincial electoral campaign that the Premier, Finance Minister, and others must have realized that a surplus was no longer a possibility. This speculation is reinforced by what is seen as the rapid reversal of the government's position once the election was over. However, none of this speculation can be verified from what is known publicly.

In order to search for the truth, it seems unavoidable that access should be sought to relevant cabinet documents or discussions. Such access, to say the least, will not be readily granted by the government. However, decisions by Canadian courts in recent years have not recognized a blanket immunity for cabinet documents. In general, the courts have acted consistently with the principle laid down by the Supreme Court of Canada in Carey v. Ontario: "Cabinet documents like other evidence must be disclosed unless such disclosure would interfere with the public interest." ${ }^{3}$ La Forest J. wrote in that case:

The appellant here alleges unconscionable behaviour on the part of the government. As I see it, it is important that this question be aired not only in the administration of justice, but also for the purpose for which it is sought to withhold the documents, namely, the proper functioning of the executive branch of government. For if there has been harsh or improper conduct in the dealings of the executive with the citizen, it ought to be revealed. The purpose of secrecy in government is to promote its proper functioning, not to facilitate improper conduct by the government."

An attempt in the mid-1980s by the Auditor General of Canada to gain access to ministerial documents relating to Petro-Canada was ultimately unsuccessful, but in the Federal Court Trial Division Jerome C.J. ruled that the government could not claim general protection from disclosure because of any constitutional convention relating to cabinet confidentiality. ${ }^{5}$ In 1989, the Nova Scotia Court of Appeal ruled that limited

[1986] 2 S.C.R. 637 at 670 [hereinafter Carey]. This decision followed the reasoning of Smallwood v. Sparling, [1982] 2 S.C.R. 686 [hereinafter Smallwood]. See the earlier decision of the British Columbia Court of Appeal in Gloucester Properties Lid. v. British Columbia (A.G.) (1981), (1982) 129 D.L.R. (3d) 275 (B.C.C.A.) [hereinafter Gloucester] which also ruled that there was no absolute privilege for cabinet documents.

Carey, ibid. at 673.

Canada (Auditor General) v. Canada (Minister of Energy, Mines and Resources) (1985), (1986) 23 D.L.R. (4th) 210 (F.C.T.D.) [hereinafter Auditor General]. Subsequent decisions by the higher courts that dealt with this case refused access to the documents, but essentially because the legislative mandate of the Auditor General was found not to require access to them. Neither the Federal Court of Appeal nor the Supreme Court of Canada revisited the issue of cabinet confidentiality in their decisions (Canada (Auditor General) v. Canada (Minister of Energy, Mines and Resources) (1987), 1 F.C. 406 (F.C.A.); Canada (Auditor General) v. Canada (Minister of 
cross-examination of Nova Scotian cabinet ministers could be undertaken by the Royal Commission examining the prosecution of Donald Marshall, $\mathrm{Jr}^{6}{ }^{6}$ Some principles about access to evidence from cabinet documents or ministers emerge from these cases which may be summarized as follows:

1. There is no absolute immunity for cabinet documents or testimony from ministers.?

2. Disclosure will be required unless some pressing public interest is demonstrated in maintaining secrecy. ${ }^{8}$

3. The administration of justice requires access to documents that are central to the proceedings. The more crucial they are to the proceedings, the more likely it is that documents will be ordered released. ${ }^{9}$

4. Access to the oral testimony of ministers is decided on the same basis as access to written material. ${ }^{10}$

5. Disclosure is more likely when some wrongdoing by the executive is alleged. Secrecy is not meant to protect malfeasance."

6. The importance of the policy covered in cabinet material is a relevant consideration. The less important the policy, the more likely disclosure will be ordered. ${ }^{12}$

7. The amount of elapsed time between cabinet events and judicial proceedings should be considered. The longer the time since the events, the less pressing is the need for secrecy. ${ }^{13}$

Energy, Mines and Resources), [1989] 2 S.C.R. 49). For a discussion on the constitutional conventions relating to cabinet confidentiality, see A. Heard, Canadian Constitutional Conventions: The Marriage of Law and Politics (Toronto: Oxford University Press, 1991) at 65-68. Nova Scotia (A.G.) v. Nova Scotia (Royal Commission into Marshall Prosecution) (1988), (1989) 54 D.L.R. (4th) 153 (N.S.C.A.) [hereinafter Marshall (C.A.)]. The Supreme Court of Canada heard an appeal by Donald Marshall's lawyer, but ruled that under the terms of reference given the Commission, it could decide not to ask questions about individual minister's views (Nova Scotia (A.G.) v. Nova Scotia (Royal Commission into Marshall Prosecution) (1989), (1990) 62 D.L.R. (4th) 354 (S.C.C.) [hereinafter Marshall (S.C.C.)]). Smallwood, supra note 3; Gloucester, supra note 3; Auditor General, supra note 5; Carey, supra note 3; Marshall (C.A.), ibid.; Marshall (S.C.C.), ibid.

Supra note 7.

Carey, supra note 3.

Smallwood, supra note 3; Nova Scotia (A.G.) v. Nova Scotia (Royal Commission into Marshall Prosecution) (1988), 85 N.S.R. (2d) 163 (N.S. S.C.T.D.).

Carey, supra note 3.

Smallwood, supra note 3; Carey, ibid.

Smallwood, ibid. 
8. Disclosure is less likely when the subject matter is important and of current political interest. ${ }^{14}$

9. It is a priority to protect the different views expressed by individual ministers in cabinet discussions. Collective responsibility is an important principle that must be fostered by allowing candour in cabinet discussions. $^{15}$

In applying these principles to the case at hand, the court will not have an easy task in finding the right balance. First of all, the case alleges wrongdoing, and of a very serious nature. The accusation of electoral dishonesty goes to the core of the democratic process and of the government's right to hold office. It would be extremely damaging to the provincial political system if a court found that the government which called an election deliberately misled the voters into re-electing them. It would be an abuse of power to use cabinet secrecy just to block access to evidence that the government lied. Secondly, the evidence is essential to the suit, and thus becomes an important concern for the administration of justice. Ultimately, the case can only be proven if there is evidence or testimony that clearly establishes that the government knew, or should have known, before or during the election that a budgetary surplus was no longer possible.

On the other side, the case law provides grounds for the judge to refuse access to cabinet documents and ministerial testimony in this instance. The budget process is one of the most important functions of government, as it is a matter of confidence upon which governments can be required to resign. The events are very recent, and there has been high public and partisan interest in the circumstances of the revised forecast of a budgetary deficit.

In this case, access to cabinet documents and testimony would only be granted if the court finds the public record to be compelling enough evidence that the government likely knew, or should have known, that a surplus was no longer sustainable. If the circumstantial evidence is strong enough, then the government would have a very difficult time in arguing that the public interest lies more in maintaining cabinet secrecy than in establishing the truth of the allegations. There is also an issue as to whether the court would be solely interested in determining when the facts about the financial situation became known to the cabinet, or whether it would also want access to documents and testimony about ministerial discussions concerning those facts. There may be a greater likelihood of the evidence on the government's financial status being released than specific evidence of discussion among the ministers. The broad facts about the government's financial condition that would be contained in those documents are already known, but what the court might want to add to the public record is when those facts became known to cabinet.

Another factor that the court may consider is that the suit directly involves the behaviour of cabinet members in their capacity as candidates, rather than members of 
the Executive Council. It is alleged that they lied as candidates, rather than as Premier and government. However, the alleged lies were about the party's record in government and would be based on information to which some of the candidates could only have had access because they were members of the Executive Council. It is grave enough that persons might lie in the course of their official duties as a cabinet member, but it may be even more serious that they might try to use the privilege of office to propagate, and hide, lies to their personal benefit while running for re-election.

If the court finds evidence of misrepresentation, then the next issue is whether the behaviour constituted "fraudulent means" under s. 256(2)(c) of the Election Act. Unfortunately, it is not readily apparent what this phrase means in the context of election campaigns. Dickson J., as he then was, wrote for the Supreme Court of Canada in Olan:

Courts, for good reason, have been loath to attempt anything in the nature of an exhaustive definition of "defraud" but one may safely say, upon the authorities, that two elements are essential, "dishonesty" and "deprivation". To succeed, the Crown must establish dishonest deprivation.... The element of deprivation is satisfied on proof of detriment, prejudice, or risk of prejudice to the economic interests on the victim. ${ }^{16}$

With the untested terms of s. 256 of the B.C. Election Act, ambiguities arise in the nature of both the misdeed of the perpetrator and the loss suffered by the victim. The term "fraudulent means" in the Election Act may well have as wide a range as "other fraudulent means" in the Criminal Code, which is a broad category whose reach is determined by community standards of honest dealings. ${ }^{17}$ Canadian courts have taken somewhat different approaches to the nature of the dishonesty involved, depending upon whether the case involved criminal or civil fraud. In civil cases, the courts have tended to imply that an intent to deceive is an essential element that needs to be proved. ${ }^{18}$ In the criminal context, however, the courts have indicated that the intent of the accused is not determinative; the dishonesty should be determined by what the reasonable person would make of the congruity between the facts that should have been known to the accused and their statements. As McLachlin J. wrote for the majority of the Supreme Court of Canada in Therroux, "[t]he personal feeling of the accused about the morality or honesty of the act or its consequences is no more relevant to the analysis than is the accused's awareness that the particular acts undertaken constitute a criminal offence." If If the Election Act phrase "fraudulent means" is analogous to the "other fraudulent means" of the Criminal Code, then the behaviour that constitutes fraud would, as McLachlin J. wrote, "be determined by what reasonable people consider to be dishonest dealing." ${ }^{20}$ In the case at hand, then, it would mean that it does not matter if the candidates intended to deceive the electors or had a reckless

R. v. Olan, [1978] 2 S.C.R. 1175 at 1182.

The general fraud offence in the Criminal Code reads in part: "Every one who, by deceit, falsehood or other fraudulent means..." R.S.C. 1985, c. C-46, s. 380(1).

L.C.H. Hoyano, "Lies, Recklessness and Deception: Disentangling Dishonesty in Civil Fraud" (1996) 75 Can. Bar Rev. 474.

$R$ v. Théroux (1993), 100 D.L.R. (4th) 624 at 635.

Ibid. at 633. See also $R$ v. Long (1990), (1991) 61 C.C.C. (3d) 156 (B.C.C.A.). 
disregard for the veracity of their statements; rather, it matters whether reasonable people would consider that the candidates had dealt dishonestly with the voters.

Friesen constitutes something of a hybrid case, being civil in the nature of an application under s. 150 of the Election Act while dealing with the substance of a penal offence. The motion filed by the petitioners is for the elections of the candidates to be declared invalid because they allegedly behaved contrary to $\mathrm{s}$. 256 . This latter section creates an offence for that behaviour with a penalty of up to two years imprisonment. It seems only logical that the candidates should be judged in this proceeding by the terms of the offence they are said to have committed. Thus, the candidates' behaviour should be examined according to the tests for criminal fraud, in which case the standard to be used is whether reasonable people would view the candidates' behaviour as honest or not.

However, the perspective of the "reasonable person" is notoriously evasive and contextual. In this case, one would have to decide what standards one can expect of candidates in an election - and those standards of behaviour may be different from the standards in other dealings. Do electors really expect to believe what politicians tell them during election campaigns? After all, there is much informal discussion in Canadian political lore about neither politicians nor election promises being something that one should put much trust in. However, the problems faced by Sheila Copps in 1996 indicate that in principle electors do expect basic honesty in campaign promises. Copps got into trouble because she had promised during the 1993 federal election to resign if her party did not scrap the GST. When it became clear that the Liberal government would not rescind the GST, Copps tried to shrug off her commitment by saying that her statement was one made in the heat of the campaign and should not be taken as a real promise. However, she eventually resigned her seat under pressure and ran successfully in the ensuing by-election. A Gallup Poll conducted just after her resignation revealed that 83 percent of Canadians believed that she was right to resign because of her election promise. ${ }^{21}$ The strength of that poll data indicates that Canadians do expect candidates to deal with them honestly and to keep election commitments they phrased as promises. Thus, the reasonable person standard that could be applied in Friesen is one in which candidates are expected to deal truthfully with the voters and promises are regarded as real commitments.

The second broad problem in defining "fraudulent means" in the Election Act context relates to the nature of the deprivation that the victim suffers because of the dishonest behaviour. It is not sufficient in a fraud context just to say that someone lied or acted dishonestly. The dishonest dealings have to be related to some actual, or risk of, deprivation. But this deprivation is viewed in other contexts as having an economic basis, which may be only one of several suitable notions of deprivation for fraud in an election context.

21 R.G. Edwards \& J. Hughes, "Public Has Mixed Feelings Over Copps Resignation" 56:41 The Gallup Poll (5 June 1996) at 2. 
Following traditional views of fraud, the loss can clearly be given an economic connotation; thus someone might be induced to vote under a false promise of a job or business contract. While that example would not be controversial, another more controversial instance of an economic context could arise when voters are falsely promised monetary benefits, such as improved welfare payments or lower taxes. Welfare payments would clearly be an economic interest for the voter and could be falsely promised in two ways: a candidate might tell the voter that they will get on the welfare rolls without a problem if they vote the right way, or there might be a false promise of a change to the general welfare rates. In either case, the voter is being falsely lured into voting for a certain candidate because of some pecuniary interest.

However, the loss involved in the fraud might have a broader context. In the case at hand, the voters may have believed they would gain from the promised increase in capital spending on schools and roads. Other victims may suffer a less tangible loss relating to broad public policy. For example, some might view it as a loss if the Reform Party were elected federally but did not deliver on their promise to create a "Triple-E" Senate.

Another type of deprivation may be more ephemeral but go more deeply into the nature of fraudulent election campaigns. The loss in the value of a citizen's electoral franchise, because he or she would have voted for someone else had they known the truth, was quite clearly at stake for the plaintiffs in Friesen. They believe that they were lied to, and they state that they would have chosen to vote for another party had they known the truth. The right to vote is fundamental to our system of government and is protected under s. 3 of the Charter of Rights and Freedoms. ${ }^{22}$ In the cases dealing with $\mathrm{s}$. 3, the courts have made it abundantly clear that the right to vote involves much more than just being able to mark a ballot; notions of effective representation and voting power have been highlighted by the courts in dealing with riding boundaries. ${ }^{23}$ More to the point of the Friesen case, the Alberta Court of Appeal recognized a right of voters to be informed on election issues in a case dealing with restrictions on nonparty advertising during campaigns. ${ }^{24}$ One could argue that the franchise can only be effectively exercised when the choices put to voters by the candidates are truthful statements of their intentions; dishonest campaigning diminishes the value of the citizens' votes. This kind of deprivation caused by dishonest campaigning might arguably be covered by s. 256 of the B.C. Election Act. Since the Act is concerned with setting rules for a fair and legitimate election, references to fraudulent means in that $A c t$ might be taken in a context that goes beyond economic loss to matters involved in exercising the franchise. 
Before deciding on the range of behaviour to include within electoral fraud, however, it is instructive to review briefly a range of campaign promises published by parties in some recent elections. The Reform Party of B.C. and the Reform Party of Canada have both published "guarantees" of what they will do if elected to office. For the 1996 provincial election, the Reform Party of British Columbia created a "Voters' Warranty" that included as its first point: "All formal election commitments made by the Leader on behalf of Reform B.C. will be honoured within our first term as government and guaranteed under this Voters' Warranty."25 Voters could seemingly rely on this document as some real promise that the Reform Party had to fulfill. However, unforeseen circumstances may well make some election promises not only unwise but impossible. Has Reform B.C. been reckless in making such a commitment? Would it be seen as a fraudulent means to attract voters when Reform B.C. should know that no party can guarantee to fulfill every single one of its promises? ${ }^{26}$ The Reform Party of Canada also made a variety of commitments to the voters during the 1996 federal election in its "Fresh Start" platform. One of its statements was that "A Reform Government will: ... replace the current undemocratic, unrepresentative Senate with a Senate that is elected, equal and effective."27 And yet, this is a commitment that no federal government can be sure of keeping, since the creation of a "Triple-E" Senate can only be achieved through a formal constitutional amendment that requires the consent of seven provinces with 50 percent of the population. The party made a promise that is beyond its own power to ensure is achieved.

In a different vein, the Natural Law Party of Canada campaigned on a platform that many Canadians would find difficult to believe. In one of its campaign publications, the leader of the Natural Law Party was quoted as saying, "When, in the last federal election Canadians did not vote for the Natural Law Party, they lost the opportunity to create a perfect government and a problem-free nation." 28 Natural Law promised to achieve this by setting up a group of 10,000 yogic flyers who would "radiate an influence of harmony and positivity in the nation which will support all facets of individual and national life." 29 Furthermore, they promised: "The Natural Law Party will create a crime-free Canada by reducing stress in the individual and society as a whole, and by developing in the whole population the ability to think and act spontaneously in accord with Natural Law."30 While some Canadians may believe these messages, many will view them as humorous at best. The reasonable persons test can easily result in the view that it is reckless to promise a "crime-free Canada" and to tout the benefits of 10,000 yogic flyers.

“Voters' Warranty" Vancouver Sun (3 May 1996) A19.

For example, in the Liberal Party of Canada's own assessment of its 1993 campaign promises, about 78 percent had been achieved within 36 months of coming to office; that leaves a significant number uncompleted. Liberal Party of Canada, A Record of Achievement: $A$ Report on the Liberal Government's 36 Months in Office (Ottawa: Liberal Party of Canada, 1996) at 9.

Reform Party of Canada, "A Fresh Start on Accountability" (http://politicscanada.com/platforms/ reform/guarantee.html), (6 June 1997).

(http://www.natural-law.ca/pdf/pagel-4.pdf), (6 June 1997).

(http://www.natural-law.ca/pdf/page8-9.pdf), (6 June 1997).

(http://www.natural-law.ca/pdf/page22-23.pdf), (6 June 1997). 
In addition to impractical promises, candidates and parties have often made commitments during campaigns that they end up reversing after coming to office. For example, Pierre Trudeau's government brought in wage and price controls only a few months after campaigning against them in the 1974 general election. Brian Mulroney negotiated the Free Trade Agreement with the United States after rejecting it in the 1984 election. And, the Chretien government decided not to rescind the GST, despite a 1993 campaign promise to do so. On most occasions, the government claims that new realities make it unwise and not in the nation's interest to implement their original promise. It is up to the voters to decide whether the parties had made false promises in the first place. ${ }^{31}$

These examples of questionable campaign promises serve as a reminder of campaign realities. Political parties and candidates often make exaggerated statements, and sometimes unsupportable or even wild promises. It is up to the electorate to sort through the chaff and determine who deserves their vote. If a party does not live up to its promises, or it turns out later that a party has embellished its record, the electorate has an opportunity at the next election to vote for someone else. ${ }^{32}$ And yet, the court in Friesen will have to balance these political realities with the fact that the B.C. legislature has created an offence of using fraudulent means to induce someone to vote for, or against, a candidate. Clearly the legislature does not believe that the ballot box should be the only way to redress or judge dishonest campaigning.

Friesen involves both novel and thought-provoking issues for the court to tackle. Uitimately, the court may have to balance the respective roles of judges and voters as it weighs competing views of what constitutes fraudulent behaviour in election campaigns. Perhaps the best balance to be followed lies in applying only the traditional notion of economic deprivation to s. 256, rather than the other, broader types of loss reviewed above. Fraudulent behaviour that deprives or endangers some economic interest has been a subject that the courts have proven quite well equipped to assess. However, the nature and significance of broader political deprivations may be best left to the judgment of the ballot box. Elections are in their very nature a competition of candidates in which the voters decide whose promises and statements to believe and prefer. If the courts expand the notion of election fraud to include the general honesty of candidates' campaign platforms, they risk insinuating themselves into the very exercise of the franchise rather than protecting it. 